\title{
Phenolic composition and antioxidant, antimicrobial and cytotoxic properties of hop (Humulus lupulus L.) Seeds
}

\author{
José Ignacio Alonso-Esteban ${ }^{\mathrm{a}}$, José Pinela ${ }^{\mathrm{b}}$, Lillian Barros ${ }^{\mathrm{b}}$, Ana Ćirićc, Marina Sokovićc \\ Ricardo C. Calhelha ${ }^{\mathrm{b}}$, Esperanza Torija-Isasa ${ }^{\mathrm{a}}$, María de Cortes Sánchez-Mata ${ }^{\mathrm{a}}$, \\ Isabel C.F.R. Ferreira ${ }^{\text {, }}$ * \\ ${ }^{a}$ Department of Nutrition and Food Science, Faculty of Pharmacy, Complutense University of Madrid, Plaza Ramón y Cajal s/n, 28040, Madrid, Spain \\ ${ }^{\mathrm{b}}$ Centro de Investigação de Montanha (CIMO), Instituto Politécnico de Bragança, Campus de Santa Apolónia, 5300-253, Bragança, Portugal \\ c University of Belgrade, Department of Plant Physiology, Institute for Biological Research "Siniša Stanković", Bulevar despota Stefana 142, Belgrade, Serbia
}

\section{A R T I C L E I N F O}

\section{Keywords:}

Hop seeds

catechin/epicatechin

Antioxidant activity

Antimicrobial activity

Cytotoxic activity

\begin{abstract}
A B S T R A C T
Hop (Humulus lupulus L.) is a perennial climbing plant cultivated for commercial use, mainly in brewing industry, since the female inflorescences (cones) contain lupulin glands that confer the characteristic bitterness, aroma and flavour to beer. However, the bioactive potential of the seeds found in these cones remains unexplored. In this study, the phenolic composition of hop seeds was analysed by LC-DAD-ESI/MS ${ }^{\mathrm{n}}$ and its antioxidant, cytotoxic and antimicrobial activities were screened against oxidizable substrates, human tumour and non-tumour cell lines, and different bacteria and fungi, respectively. (+)-Catechin and (-)-epicatechin were identified in the seeds, totalizing $17.6 \pm 0.7 \mathrm{mg} / \mathrm{g}$ extract. The seed extract showed antioxidant activity mainly through the formation inhibition of thiobarbituric acid reactive substances (TBARS), and had cytotoxic effects against MCF-7 (breast adenocarcinoma), NCI-H460 (non-small cell lung cancer), HeLa (cervical carcinoma), and HepG2 (hepatocellular carcinoma) tumour cells, but no toxicity towards the normal PLP2 cell line was observed. The extract showed remarkable antimicrobial properties, being better than the positive controls against almost all tested bacteria and fungi of the genus Penicillium. These results highlight the potential of hop seeds as a source of functional ingredients with applications in the food and pharmaceutical sectors.
\end{abstract}

\section{Introduction}

Humulus lupulus $\mathrm{L}$. (hop) is one of the three species of the genus Humulus that belongs to the family Cannabaceae. The origin of the genus has been suggested to be China, from where eastward and westward migrations to America and Europe, respectively, took place. The species has been classified into five taxonomic varieties based on their morphological characteristics and geographical locations (Small, 1980, 1978). The cultivation of this plant for long time caused the existence of different cultivars and chemotypes. The main reason was the need to choose specific organoleptic properties of hops, in order to improve the flavour and aroma of beer, one of the oldest and most widely consumed alcoholic drinks worldwide (Zanoli and Zavatti, 2008).

Hop is an industrial plant massively used in the brewing industry. The female hop inflorescences (cones or strobiles) have lupulin glands that contain different compounds, such as resins, bitter acids, essential oils, and flavonoids, which play an important role in the brewing process. These compounds improve the preservation of beer and provide bitterness (Karabin et al., 2015). Bitter acids are phloroglucinol prenylated derivatives and are generally classified as $\alpha$-acids and $\beta$ acids; the most important are humulone and lupulone, respectively (Zanoli and Zavatti, 2008). Hop has different types of flavonoids, such as flavan-3-ols, proanthocyanidins, flavonols, flavanones, and prenylflavonoids, which have prenyl or geranyl chains on the flavonoid structure. The most important prenylflavonoid is xanthohumol, a chalcone that can be converted to the flavanone isoxanthohumol in consequence of brewing conditions. Isoxanthohumol is therefore the main prenylflavonoid present in beer (Karabin et al., 2015).

Apart from brewing industry, hop cones has been used in traditional medicine to control anxiety, spasms, cough, fever, toothache, and inflammation; and hop resins have been applied as a mild sedative (Chattopadhyay, 2010). In fact, the health-promoting effects and bioactivities of hop flavonoids are numerous and the most outstanding are the cardioprotective effect and the antioxidant, anti-inflammatory, anticarcinogenic, and antimicrobial activities (Karabin et al., 2015;

\footnotetext{
* Corresponding author.

E-mail address: iferreira@ipb.pt (I.C.F.R. Ferreira).
} 
Stevens and Page, 2004). Because of this, there is a growing interest in the possible use of the hop plant for non-brewing purposes, especially in the pharmaceutical and nutraceutical industries.

The hop cones are the most used part of the plant, but there are other parts that also have an interest as food. Hop shoots with little leaves are eaten stewed in a traditional way in Spain, whose nutritional composition and antioxidant properties have already been described (Tardío et al., 2016). In addition, there are also reports on the antioxidant and antimicrobial activities of hop cones and leaves (Abram et al., 2015). However, as far as we know, the bioactive potential of the seeds found in the cones of this plant remains unexplored. Therefore, this study aimed to characterize the phenolic composition and to evaluate the antioxidant, antimicrobial (antibacterial and antifungal), and cytotoxic properties of hop seeds.

\section{Materials and methods}

\subsection{Plant material and extract preparation}

Hop seed samples were purchased from Semillas Cantueso, S.L., Spain, a certified seed company that collects, produces and commercialises seeds of the Iberian Peninsula flora with ecological certification. The seeds were reduced to a fine powder ( 20 mesh), which was subjected to a solid-liquid extraction with methanol:water $(80: 20, v / v)$ as previously described by Pinela et al. (2012). The extraction yield was calculated and expressed as g extract per $100 \mathrm{~g}$ hop seeds.

\subsection{Analysis of phenolic compounds}

The dry extract ( $\sim 10 \mathrm{mg})$ was dissolved in methanol:water $(20: 80, v /$ $v ; 2 \mathrm{~mL}$ ) and filtered through a $0.22-\mu \mathrm{m}$ syringe filter disk. The LC-DADESI/MS ${ }^{\mathrm{n}}$ analysis was performed on a Dionex Ultimate 3000 UPLC with a diode array detector (DAD, 280, 330 and $370 \mathrm{~nm}$ ) coupled to a Linear Ion Trap LTQ XL mass spectrometer (Thermo Scientific, San Jose, CA, USA). The chromatographic conditions and procedures used to identify and quantify the phenolic compounds were previously described by Bessada et al. (2016). The results were expressed as mg per $g$ of dry extract.

\subsection{Evaluation of bioactive properties}

\subsubsection{Antioxidant activity}

The antioxidant activity of the extract (at concentrations from 2.5 to $0.039 \mathrm{mg} / \mathrm{mL}$ ) was evaluated in vitro by the DPPH free radical scavenging capacity, reducing power, $\beta$-carotene bleaching inhibition, and thiobarbituric acid reactive substances (TBARS) formation inhibition assays, as described previously by Pinela et al. (2012). Trolox (Sigma-Aldrich, St. Louis, MO, USA) was used as positive control. Results were given as $\mathrm{EC}_{50}$ values $(\mu \mathrm{g} / \mathrm{mL})$.

\subsubsection{Cytotoxic and hepatotoxic activities}

The sulforhodamine B assay was performed to evaluate the cytotoxic activity of the extract (at concentrations from 4 to $0.125 \mathrm{mg} / \mathrm{mL}$ ) against the MCF-7 (breast adenocarcinoma), NCI-H460 (non-small cell lung cancer), HeLa (cervical carcinoma) and HepG2 (hepatocellular carcinoma) human tumour cell lines (Vaz et al., 2010). The assay was also performed to evaluate the hepatotoxicity of the extract against non-tumour primary cells (PLP2) (Pereira et al., 2013). The procedures and the origin of cell lines were previously described by the authors. Ellipticine (Sigma-Aldrich) was used as positive control. Results were given as $\mathrm{GI}_{50}$ values $(\mu \mathrm{g} / \mathrm{mL})$.

\subsubsection{Antimicrobial activity}

The extract (at concentrations from 5 to $0.005 \mathrm{mg} / \mathrm{mL}$ ) was tested against Bacillus cereus (food isolate), Staphylococcus aureus (ATCC 11,632), Listeria monocytogenes (NCTC 7973), and Enterococcus faecalis (ATCC 19,433) (Gram-positive bacteria) and Escherichia coli (ATCC 35,218) and Salmonella typhimurium (ATCC 13,311) (Gram-negative bacteria) (Soković et al., 2010). The fungi Aspergillus fumigatus (ATCC 1022), Aspergillus ochraceus (ATCC 12,066), Aspergillus niger (ATCC 6275), Penicillium ochrochloron (ATCC 9112), Penicillium funiculosum (ATCC 36,839), and Penicillium verrucosum var. cyclopium (food isolate) were also tested (Soković and van Griensven, 2006). The procedures and the origin of the microorganisms were previously described by the authors. As positive controls (Sigma-Aldrich), streptomycin and ampicillin were used for the antibacterial activity, while ketoconazole and bifonazole were used for the antifungal activity. The results were given as minimum inhibitory (MIC) and minimum bactericidal (MBC) or minimum fungicidal (MFC) concentrations $(\mathrm{mg} / \mathrm{mL})$.

\subsection{Statistical analysis}

The experiments were carried out in triplicate and the results were expressed as mean \pm standard deviation. The SPSS Statistics software (IBM SPSS Statistics for Windows, Version 22.0. Armonk, NY: IBM Corp.) was used to analyse differences among hop seed extract and positive control in the antioxidant and cytotoxicity assays by applying a two-tailed paired Student's $t$-test at a $5 \%$ significance level. Significant differences between the samples were considered when the $p$-value was lower than 0.05 .

\section{Results and discussion}

\subsection{Extraction yield}

The solid-liquid extraction yielded $6.0 \pm 0.3 \mathrm{~g}$ of extract per $100 \mathrm{~g}$ of hop seeds. This low yield may be justified by the hardness of the seeds, which also affects the germination. The value is within the range achieved by Chen et al. (2012) for hempseed (Cannabis sativa L.) kernel (0.45-14.97\%). For extraction, the authors used methanol, ethanol and acetone at different concentrations, and verified that the higher yields were obtained when using the more polar solvent. They also reported a higher amount of soluble substances in the hempseed kernel than in the hull, which gave a lower yield (0.18-3.29\%). In our study, the hop seed was analysed whole because of its very small size.

Table 1

Identified compounds, retention time (Rt), wavelengths of maximum absorption ( $\left.\lambda_{\max }\right)$, mass spectral data, relative abundances of ions, and quantified amount of phenolic compounds in hop seeds.

\begin{tabular}{llllll}
\hline Compound & Rt $(\min )$ & $\lambda_{\max }(\mathrm{nm})$ & Pseudomolecular ion $[\mathrm{M}-\mathrm{H}]^{-}(\mathrm{m} / \mathrm{z})$ & $\mathrm{MS}^{2}$ fragments $(\mathrm{m} / \mathrm{z})$ & Content $(\mathrm{mg} / \mathrm{g}$ extract) \\
\hline (+)-Catechin & 7.1 & 278 & 289 & $245(100), 205(37), 179(13), 165(5), 137(3)$ & $13.7 \pm 0.5$ \\
(-)-Epicatechin & 9.7 & 279 & 289 & $245(100), 205(35), 179(15), 165(8), 137(3)$ & $3.9 \pm 0.2$ \\
$\Sigma$ & & & & & $17.6 \pm 0.7$
\end{tabular}

Calibration curves: $(+)$-catechin $\left(y=84950 x-23,200 ; r^{2}=0.9999 ; \quad\right.$ LOD $=0.17 \mu \mathrm{g} / \mathrm{mL} ;$ LOQ $\left.=0.68 \mu \mathrm{g} / \mathrm{mL}\right) ;(-)$-epicatechin $(y=10314 x+147,331$; $r^{2}=0.9994 ; \mathrm{LOD}=0.21 \mu \mathrm{g} / \mathrm{mL} ; \mathrm{LOQ}=0.84 \mu \mathrm{g} / \mathrm{mL}$ ).

${ }^{\text {a }}$ The results are presented as mean \pm standard deviation. 
<smiles>Oc1cc(O)c2c(c1)C[C@@H](c1ccc(O)c(O)c1)[C@H](O)O2</smiles><smiles>Oc1cc(O)c2c(c1)C[C@@H](c1ccc(O)c(O)c1)[C@H](O)O2</smiles>

Fig. 1. Chemical structure of (A) (+)-catechin and (B) (-)-epicatechin.

\subsection{Phenolic composition}

The phenolic compounds (+)-catechin and (-)-epicatechin were identified in the hop seed extract. Data related to the identification of these two compounds are given in Table 1 and their chemical structure is shown in Fig. 1. Both compounds were identified based on their chromatographic characteristics and UV-vis and mass spectra as compared with commercial standards. (+)-Catechin was found as the most abundant compound (13.7 $\pm 0.5 \mathrm{mg} / \mathrm{g}$ extract) in hop seeds, followed by (-)-epicatechin $(3.9 \pm 0.2 \mathrm{mg} / \mathrm{g}$ extract). Thus, $1 \mathrm{~g}$ of hop seed hydromethanolic extract contained $17.6 \pm 0.7 \mathrm{mg}$ of total flavan-3-ols. These compounds have been previously described in hop. Keskin et al. (2018) found catechin in hop cones $(0.37 \mathrm{mg} / \mathrm{g}$ of methanolic extract) and epicatechin in hop leaves $(0.83 \mathrm{mg} / \mathrm{g}$ of methanolic extract). According to Inui et al. (2017), the content of these polyphenols in hop cones can change depending on the time and year of harvest. The authors reported a decrease in late harvest samples and a catechin/epicatechin ratio ranging from 5 to 11 (in the hop seeds, the ratio is 3.5). Karabin et al. (2015) report in a research review that hop flavonoids (with the exception of prenylflavonoids) are present in all parts of hop cones, especially in seeds and bracts, and that the contents can be affected by several factors including variety, edaphoclimatic conditions, cultivation techniques, and storage conditions, among others. Additionally, some studies report that $(+)$-catechin is absent in beers (Arts et al., 2000), while others describe low amounts, close to $0.5 \mathrm{mg} / \mathrm{L}$ (Bartolomé et al., 2000).

(+)-Catechin and (-)-epicatechin have been also identified in hempseed, a plant of the same family than hop, but in a much lower quantity. Smeriglio et al. (2016) quantified $5.3 \mu \mathrm{g} / 100 \mathrm{~g}$ and $10.2 \mu \mathrm{g} /$ $100 \mathrm{~g}$ of (+)-catechin and (-)-epicatechin, respectively, in the methanolic extract of hempseed oil. Multari et al. (2016), on the other hand, described $166 \mu \mathrm{g} / 100 \mathrm{~g}$ of $(+)$-catechin and $46 \mu \mathrm{g} / 100 \mathrm{~g}$ of (-)-epicatechin in commercial hemp flour.

Catechins are found in other seeds, such as cocoa and grape, which are responsible for the high catechin content found in dark chocolate $(46-61 \mathrm{mg} / 100 \mathrm{~g})$ and red wine $(8-30 \mathrm{mg} / 100 \mathrm{~g})$, respectively; although green tea from Camellia sinensis L. leaves is the main source $(10-80 \mathrm{mg} / 100 \mathrm{~g}$ ) of these compounds (Gadkari and Balaraman, 2015).
It should also be noted that cocoa and grape seeds contain complex compounds derived from flavan-3-ols, such as procyanidins (Fayeulle et al., 2018; Ma et al., 2018), whereas hop seeds only contained the monomers.

(+)-Catechin and (-)-epicatechin are compounds of great importance in different industrial sectors. These are widely used as functional ingredients in functional foods, dietary supplements, and nutraceuticals to promote consumers health, prevent various diseases, and extend the product shelf-life, but also in different pharmaceutical and cosmetic formulations (Gadkari and Balaraman, 2015; Yilmaz, 2006). Given the high added value of these compounds, several studies have focused on novel methods to optimized their extraction from plant matrices (Albuquerque et al., 2017a) and techniques to promote their stability (Albuquerque et al., 2017b), before being incorporated into final products (such as food, pharmaceuticals, or active food packaging films) (Arrieta et al., 2017; Takwa et al., 2018). The present study showed for the first time that hop seeds are an interesting source of (+)-catechin and (-)-epicatechin, compared with other matrices described in the literature (Gadkari and Balaraman, 2015).

\subsection{Antioxidant activity}

The results of the antioxidant activity of the hop seed extract are given in Table 2 . The lower the $\mathrm{EC}_{50}$ values, the higher the antioxidant activity. The TBARS assay gave the lowest $\mathrm{EC}_{50}$ value, being required $128 \pm 2 \mu \mathrm{g} / \mathrm{mL}$ to provide $50 \%$ of antioxidant activity. This assay measures the extract capacity to inhibit the formation of malondialdehyde and other low-molecular weight end products that are generated from the ex vivo decomposition of certain lipid peroxidation products (Alonso et al., 2009). Porcine brain cells were used for this purpose because they are biological substrates rich in polyunsaturated fatty acids and, therefore, good models for lipid peroxidation studies.

The hop extract had comparable $\mathrm{EC}_{50}$ values for the DPPH free radical scavenging capacity $(505 \pm 16 \mu \mathrm{g} / \mathrm{mL})$ and reducing power $(530 \pm 16 \mu \mathrm{g} / \mathrm{mL}$ ) (Table 2). DPPH was used as a source of free radicals, since it simulates in vitro the reactive oxygen and nitrogen species (ROS and RNS) that affect biological systems. Furthermore, it is considered that the mechanism of ROS/RNS scavenging by antioxidants is involved in the inhibition of oxidative stress-induced cellular damage and lipid peroxidation (Panat et al., 2016). On the other hand, the reducing power or ferricyanide/Prussian blue assay allowed to estimate the reductant compounds in the hop extract.

The highest $\mathrm{EC}_{50}$ value $(1330 \pm 74 \mu \mathrm{g} / \mathrm{mL})$ was achieved with the $\beta$-carotene/linoleic acid antioxidant activity assay (Table 2 ). This result may indicate that the hop extract is less efficient in neutralizing the linoleic hydroperoxyl radicals (and also lipid hydroperoxides,

Table 2

Antioxidant, anti-proliferative and hepatotoxic properties of hop seed extract and positive controls (trolox or ellipticine).

\begin{tabular}{lll}
\hline & Hop seed extract & Positive control \\
\hline Antioxidant activity (EC $_{50}$ values, $\left.\mu \mathrm{g} / \mathrm{mL}\right)^{\mathrm{a}}$ & & Trolox \\
DPPH free radical scavenging activity & $505 \pm 16$ & $42 \pm 1$ \\
Reduction power & $530 \pm 16$ & $41 \pm 1$ \\
$\beta_{\text {-Carotene bleaching inhibition capacity }}$ & $1330 \pm 74$ & $18 \pm 1$ \\
TBARS formation inhibition capacity & $128 \pm 2$ & $23 \pm 1$ \\
Cytotoxic activity (GI 50 values, $\mu \mathrm{g} / \mathrm{mL})^{\mathrm{a}}$ & & Ellipticine \\
HepG2 (hepatocellular carcinoma) & $278 \pm 4$ & $13 \pm 1$ \\
NCI-H460 (non-small cell lung carcinoma) & $184 \pm 6$ & $8.0 \pm 0.2$ \\
HeLa (cervical carcinoma) & $244 \pm 21$ & $4.75 \pm 0.05$ \\
MCF-7 (breast carcinoma) & $251 \pm 9$ & $3.7 \pm 0.2$ \\
Hepatotoxicity (GI & & Ellipticine \\
PLP2 (liver primary culture) $\mu \mathrm{g} / \mathrm{mL})^{\mathrm{a}}$ & $>400$ & $8.6 \pm 0.1$ \\
\hline
\end{tabular}

a The results are presented as mean \pm standard deviation. Statistical differences were found between hop seed extract and positive control when using a two-tailed paired Student's $t$-test. 
conjugated dienes and volatile by-products), which are generated in the in vitro system from the oxidation of linoleic acid, since these radicals attack $\beta$-carotene and cause the bleaching of the reaction emulsion (Frankel, 2005; Sowndhararajan and Kang, 2013).

Table 2 also shows that a lower concentration of trolox (the used positive control) was required to induce antioxidant effects $\left(\mathrm{EC}_{50}\right.$ values $\leq 42 \pm 1 \mu \mathrm{g} / \mathrm{mL}$ ). However, it should be noted that trolox is a pure antioxidant compound, whereas hop extract is a complex mixture of different phytochemicals with or without bioactive properties. Furthermore, according to the literature, catechins have remarkable antioxidant properties, being able to neutralize ROS, reduce metal ions, and inhibit lipid peroxidation (Grzesik et al., 2018). In fact, the antioxidant activity of (+)-catechin and (-)-epicatechin is much higher than that of prenylflavonoids (measured via DPPH assay), compounds also reported in hop (Inui et al., 2017).

In a previous study, Morales et al. (2012) evaluated the antioxidant activity of methanolic extracts of hop young shoots and also achieved the lowest $\mathrm{EC}_{50}$ value ( $\left.\sim 30 \mu \mathrm{g} / \mathrm{mL}\right)$ with the TBARS assay. This extract was more effective in inhibiting the discoloration of $\beta$-carotene than the seed extract (with an $\mathrm{EC}_{50}$ value of $\sim 480 \mu \mathrm{g} / \mathrm{mL}$ ), but it had a worse performance for the DPPH free radical scavenging and reducing power assays (with $\mathrm{EC}_{50}$ values of $\sim 1360$ and $\sim 800 \mu \mathrm{g} / \mathrm{mL}$, respectively). The authors measured $9.56 \pm 0.65 \mathrm{mg}$ of $(+)$-catechin equivalents per $\mathrm{g}$ extract (total flavonoids), a content lower than that quantified in the seeds, which may justify the variations in antioxidant capacity.

It was also already demonstrated that ethanolic extracts of hop cones have better DPPH radical scavenging properties and a higher phenolic content than the leaves (Abram et al., 2015).

For hempseed extracts obtained by using different solvent systems, better scavenging activities for DPPH and 2,2'-azino-bis(3-ethylbenzothiazoline-6-sulphonic acid) (ABTS) radical were reported for those obtained from hulls ( $\mathrm{IC}_{50}$ values around $90-2210 \mu \mathrm{g} / \mathrm{mL}$ and $12-138 \mu \mathrm{g} / \mathrm{mL}$, respectively) than kernels ( $\mathrm{IC}_{50}$ values around $580-5630 \mu \mathrm{g} / \mathrm{mL}$ and $53-485 \mu \mathrm{g} / \mathrm{mL}$, respectively) (Chen et al., 2012). This result evidenced that hempseed hull, a usually discarded waste, could be used as source of antioxidants.

\subsection{Cytotoxic and hepatotoxic activities}

The cytotoxic effects of the hop seed extract against MCF-7 (breast adenocarcinoma), NCI-H460 (non-small cell lung cancer), HeLa (cervical carcinoma), and HepG2 (hepatocellular carcinoma) are shown in Table 2 . The aqueous extract had cytotoxicity against all these tumour cell lines, with $\mathrm{GI}_{50}$ values $\leq 278 \pm 4 \mu \mathrm{g} / \mathrm{mL}$. The best result was against the NCI-H460 tumour cells, with $184 \pm 6 \mu \mathrm{g} / \mathrm{mL}$ extract inhibiting $50 \%$ of the cell growth. The observed cytotoxic effects could be related to the high catechins content found in the extract. According to Kampa et al. (2000), (+)-catechin and (-)-epicatechin had a good effect on the proliferation inhibition of human prostate cancer cells. Interestingly, the hop extract had no hepatotoxic effects, up to the tested concentration $\left(\mathrm{GI}_{50}\right.$ values $>400 \mu \mathrm{g} / \mathrm{mL}$ ), against the normal cell line PLP2 (liver primary culture). To the author's best knowledge, there are no previous reports on the cytotoxic effects of hop seed extracts.

Previous studies on anti-proliferative and cytotoxic effects of hop compounds reported that xanthohumol (the most abundant prenylated flavonoid in hop cones) has a broad spectrum of chemopreventive and anticancer activities. Miranda et al. (1999) showed that it is highly effective in suppressing the growth of human breast (MCF-7) and ovarian (A-2780) cancer cells. The growth inhibition of MCF-7 cells by xanthohumol and isoxanthohumol has been associated with inhibition of DNA synthesis (Miranda et al., 1999). Xanthohumol also has strong anti-proliferative activity against A549 lung adenocarcinoma cells and RK33 laryngeal cancer cells via modulation of the extracellular signal regulated kinase (ERK) signalling pathway and induction of apoptosis (Sławińska-Brych et al., 2016, 2015). In turn, Brunelli et al. (2009) showed that 8-prenylnaringenin inhibits epidermal growth factor-
Table 3

Antimicrobial activity of hop seed extract and positive controls.

\begin{tabular}{|c|c|c|c|c|c|c|}
\hline \multirow[b]{2}{*}{ Antibacterial activity } & \multicolumn{2}{|c|}{ Hop seed extract } & \multicolumn{2}{|c|}{$\begin{array}{l}\text { Positive control } \\
1^{\mathrm{a}}\end{array}$} & \multicolumn{2}{|c|}{$\begin{array}{l}\text { Positive control } \\
2^{\mathrm{a}}\end{array}$} \\
\hline & $\begin{array}{l}\mathrm{MIC}^{\mathrm{b}} \\
(\mathrm{mg} / \\
\mathrm{mL})\end{array}$ & $\begin{array}{l}\mathrm{MBC}^{\mathrm{c}} \\
(\mathrm{mg} / \\
\mathrm{mL})\end{array}$ & $\begin{array}{l}\mathrm{MIC} \\
(\mathrm{mg} / \\
\mathrm{mL})\end{array}$ & $\begin{array}{l}\mathrm{MBC} \\
(\mathrm{mg} / \\
\mathrm{mL})\end{array}$ & $\begin{array}{l}\text { MIC } \\
\text { (mg/ } \\
\text { mL) }\end{array}$ & $\begin{array}{l}\mathrm{MBC} \\
(\mathrm{mg} / \\
\mathrm{mL})\end{array}$ \\
\hline Bacillus cereus & 0.01 & 0.02 & 0.10 & 0.20 & 0.25 & 0.40 \\
\hline Staphylococcus aureus & 0.075 & 0.15 & 0.04 & 0.10 & 0.25 & 0.45 \\
\hline Listeria monocytogenes & 0.15 & 0.30 & 0.20 & 0.30 & 0.40 & 0.50 \\
\hline Enterococcus faecalis & 0.037 & 0.075 & 0.20 & 0.30 & 0.25 & 0.50 \\
\hline Escherichia coli & 0.15 & 0.30 & 0.20 & 0.30 & 0.40 & 0.50 \\
\hline Salmonella typhimurium & 0.15 & 0.30 & 0.20 & 0.30 & 0.75 & 1.20 \\
\hline Antifungal activity & $\begin{array}{l}\mathrm{MIC}^{\mathrm{b}} \\
(\mathrm{mg} / \\
\mathrm{mL})\end{array}$ & $\begin{array}{l}\mathrm{MFC}^{\mathrm{d}} \\
(\mathrm{mg} / \\
\mathrm{mL})\end{array}$ & $\begin{array}{l}\text { MIC } \\
\text { (mg/ } \\
\mathrm{mL})\end{array}$ & $\begin{array}{l}\text { MFC } \\
(\mathrm{mg} / \\
\mathrm{mL})\end{array}$ & $\begin{array}{l}\text { MIC } \\
\text { (mg/ } \\
\mathrm{mL})\end{array}$ & $\begin{array}{l}\text { MFC } \\
(\mathrm{mg} / \\
\mathrm{mL})\end{array}$ \\
\hline Aspergillus fumigatus & 0.60 & 1.20 & 0.25 & 0.50 & 0.15 & 0.20 \\
\hline Aspergillus ochraceus & 0.15 & 0.30 & 0.20 & 0.50 & 0.10 & 0.20 \\
\hline Aspergillus niger & 0.30 & 0.60 & 0.20 & 0.50 & 0.15 & 0.20 \\
\hline $\begin{array}{l}\text { Penicillium } \\
\quad \text { ochrochloron }\end{array}$ & 0.15 & 0.30 & 0.20 & 0.50 & 0.20 & 0.25 \\
\hline Penicillium funiculosum & 0.075 & 0.15 & 2.5 & 3.5 & 0.20 & 0.25 \\
\hline $\begin{array}{l}\text { Penicillium verrucosum } \\
\text { var. cyclopium }\end{array}$ & 0.15 & 0.30 & 0.20 & 0.30 & 0.10 & 0.20 \\
\hline
\end{tabular}

${ }^{\text {a }}$ As positive controls, streptomycin and ampicillin (positive control 1 and 2, respectively) were used for the antibacterial activity, while ketoconazole and bifonazole (positive control 1 and 2, respectively) were used for the antifungal activity.

b Minimum inhibitory concentration.

c Minimal bactericidal concentration.

d Minimal fungicidal concentration.

induced MCF-7 breast cancer cell proliferation by inhibiting activation of the PI(3)K/Akt signalling pathway, which is involved in the control of cell proliferation (Brunelli et al., 2009).

Prostate cancer has also been studied with PC-3 and DU145 cell lines; several prenylflavonoids had growth inhibition activity, and the most promising was xanthohumol (Delmulle et al., 2006). Hop prenylflavonoids also inhibit breast cancer Sk-Br-3 cell line proliferation by aromatase inhibition (Monteiro et al., 2007). The anti-proliferative activity of hop compounds in cell lines of colon cancer, HT-29 and CaCo-2, was also investigated (Machado et al., 2017). Isoxanthohumol inhibited cell growth, but xanthohumol did not had anti-proliferative activity.

\subsection{Antimicrobial activity}

The results of the antibacterial activity of the hop seed extract against the tested Gram-positive and Gram-negative bacteria are presented in Table 3. The MIC and MBC values obtained for the hop seed extract were better than those of the positive controls in all tested bacteria, except for $S$. aureus (MIC of $0.075 \mathrm{mg} / \mathrm{mL}$ and MBC of $0.15 \mathrm{mg} / \mathrm{mL}$ ), which were better than ampicillin (MIC of $0.25 \mathrm{mg} / \mathrm{mL}$ and $\mathrm{MBC}$ of $0.45 \mathrm{mg} / \mathrm{mL}$ ), but worse than streptomycin (MIC of $0.04 \mathrm{mg} / \mathrm{mL}$ and $\mathrm{MBC}$ of $0.10 \mathrm{mg} / \mathrm{mL}$ ). In a previous study, Bogdanova et al. (2018) evaluated the antibiofilm activity of hop cone extracts in different Staphylococcus spp., including methicillin-susceptible and resistant strains, and achieved quite good results, except for $S$. epidermidis. Lupulone and xanthohumol were identified as the compounds responsible for such activity. A positive antibacterial co-action has also observed between these two compounds and some antibiotics, such as polymyxin B sulfate, ciprofloxacin and tobramycin (Natarajan et al., 2008). In turn, Abram et al. (2015) reported that hop cone extracts have a powerful antimicrobial activity against $S$. aureus (MIC $<0.003 \mathrm{mg}$ / $\mathrm{mL})$. However, these hop compounds were not detected in the seeds, which were particularly rich in catechins. According to the literature, these compounds also display antibacterial activity, being able to precipitate bacterial cell proteins and, consequently, to interfere in the 
formation of the cell wall (Gomes et al., 2018).

Table 3 also shows the results of the antifungal activity of the hop seed extract. For $P$. funiculosum, the MIC and MFC values of the extract $(0.075 \mathrm{mg} / \mathrm{mL}$ and $0.15 \mathrm{mg} / \mathrm{mL}$, respectively) were lower than those of the positive controls ketoconazole $(2.5 \mathrm{mg} / \mathrm{mL}$ and $3.5 \mathrm{mg} / \mathrm{mL}$, respectively) and bifonazole $(0.20 \mathrm{mg} / \mathrm{mL}$ and $0.25 \mathrm{mg} / \mathrm{mL}$, respectively), evidencing the high activity of the extract against this pathogen. The extract also had a MIC value lower than the positive controls against $P$. ochrochloron $(0.15 \mathrm{mg} / \mathrm{mL}$ vs. $0.20 \mathrm{mg} / \mathrm{mL}$, respectively), while the MFC $(0.30 \mathrm{mg} / \mathrm{mL})$ was only lower than bifonazole $(0.50 \mathrm{mg} / \mathrm{mL})$. It is also interesting to note the low MIC and MFC values against $A$. ochraceus $(0.15 \mathrm{mg} / \mathrm{mL}$ and $0.30 \mathrm{mg} / \mathrm{mL}$, respectively) and $P$. cyclopium $(0.15 \mathrm{mg} / \mathrm{mL}$ and $0.30 \mathrm{mg} / \mathrm{mL}$, respectively), which were even better than ketoconazole (MIC of $0.20 \mathrm{mg} / \mathrm{mL}$ and MFC of $0.50 \mathrm{mg} / \mathrm{mL}$ and $0.30 \mathrm{mg} / \mathrm{mL}$, respectively). Therefore, the extract was more efficient against fungi of the genus Penicillium than Aspergillus. The antifungal activity of a hop cone extract against different fungi, including Penicillium and Aspergillus strains, was demonstrated by Nionelli et al. (2018), which used it as a natural preservative to considerably extend the shelf-life of bread.

\section{Conclusions}

The recognized antioxidant flavan-3-ols, (+)-catechin and (-)-epicatechin were identified in hop seeds. The extract showed antioxidant activity mainly through the formation inhibition of TBARS generated from the ex vivo decomposition of lipid peroxidation products, and had cytotoxic effects against the tested tumour cells (MCF-7, NCI-H460, HeLa and HepG2), but it was not hepatotoxic against the normal cell line PLP2. The extract showed remarkable antimicrobial properties, being better than the positive controls against almost all tested bacteria (namely B. cereus, L. monocytogenes, E. faecalis, E. coli, and S. typhymurium) and fungi of the genus Penicillium. These results highlight the potential of hop seeds as a source of functional ingredients (natural extract or isolated compounds) with applications in the pharmaceutical and food sectors (e.g. as natural preservatives, antimicrobials, and health promoters).

\section{Acknowledgements}

The authors are grateful to the Foundation for Science and Technology (FCT, Portugal) and FEDER under Programme PT2020 for financial support to CIMO (UID/AGR/00690/2019) and the research contracts of J. Pinela (Project AllNatt, POCI-01-0145-FEDER-030463), L. Barros, and R.C. Calhelha. Also to ALIMNOVA-UCM research group and Art. 83 project ref: UCM 252/2017, and to the Rafael Folch Foundation for the J.I. Alonso-Esteban grant (2016/01M). This work was funded by the European Regional Development Fund (ERDF) through the Regional Operational Program North 2020, within the scope of Project NORTE-01-0145-FEDER-023289: DeCodE. To FEDERInterreg España-Portugal programme for financial support through the project 0377_Iberphenol_6_E. Authors are grateful also to the Ministry of Education, Science and Technological Development of Serbia (Grant No. OI 173,032).

\section{References}

Abram, V., Čeh, B., Vidmar, M., Hercezi, M., Lazić, N., Bucik, V., Možina, S.S., Košir, I.J., Kač, M., Demšar, L., Poklar Ulrih, N., 2015. A comparison of antioxidant and antimicrobial activity between hop leaves and hop cones. Ind. Crops Prod. 64, 124-134. Albuquerque, B.R., Prieto, M.A., Barreiro, M.F., Rodrigues, A., Curran, T.P., Barros, L., Ferreira, I.C.F.R., 2017a. Catechin-based extract optimization obtained from Arbutus unedo L. Fruits using maceration/microwave/ultrasound extraction techniques. Ind. Crops Prod. 95, 404-415.

Albuquerque, B.R., Prieto, M.A., Barros, L., Ferreira, I.C.F.R., 2017b. Assessment of the stability of catechin-enriched extracts obtained from Arbutus unedo L. fruits: kinetic mathematical modeling of $\mathrm{pH}$ and temperature properties on powder and solution systems. Ind. Crops Prod. 99, 150-162.
Alonso, C., Barba, C., Rubio, L., Scott, S., Kilimnik, A., Coderch, L., Notario, J., Parra, J.L., 2009. An ex vivo methodology to assess the lipid peroxidation in stratum corneum. J. Photochem. Photobiol. B, Biol. 97, 71-76.

Arrieta, M.P., Sessini, V., Peponi, L., 2017. Biodegradable poly(ester-urethane) incorporated with catechin with shape memory and antioxidant activity for food packaging. Eur. Polym. J. 94, 111-124.

Arts, I.C.W., van de Putte, B., Hollman, P.C.H., 2000. Catechin contents of foods commonly consumed in the Netherlands. 2. Tea, wine, fruit juices, and chocolate milk. J. Agric. Food Chem. 45, 1752-1757.

Bartolomé, B., Peña-Neira, A., Gómez-Cordovés, C., 2000. Phenolics and related substances in alcohol-free beers. Eur. Food Res. Technol. 210, 419-423.

Bessada, S.M.F., Barreira, J.C.M., Barros, L., Ferreira, I.C.F.R., Oliveira, M.B.P.P., 2016. Phenolic profile and antioxidant activity of Coleostephus myconis (L.) Rchb.f.: an underexploited and highly disseminated species. Ind. Crops Prod. 89, 45-51.

Bogdanova, K., Röderova, M., Kolar, M., Langova, K., Dusek, M., Jost, P., Kubelkova, K., Bostik, P., Olsovska, J., 2018. Antibiofilm activity of bioactive hop compounds humulone, lupulone and xanthohumol toward susceptible and resistant staphylococci. Res. Microbiol. 169, 127-134.

Brunelli, E., Pinton, G., Chianale, F., Graziani, A., Appendino, G., Moro, L., 2009. 8Prenylnaringenin inhibits epidermal growth factor-induced MCF-7 breast cancer cell proliferation by targeting phosphatidylinositol-3-OH kinase activity. J. Steroid Biochem. Mol. Biol. 113, 163-170.

Chattopadhyay, D., 2010. Ethnomedicine: A Source of Complementary Therapeutics. Research Signpost, Beliaghata, Kolkata.

Chen, T., He, J., Zhang, J., Li, X., Zhang, H., Hao, J., Li, L., 2012. The isolation and identification of two compounds with predominant radical scavenging activity in hempseed (seed of Cannabis sativa L.). Food Chem. 134, 1030-1037.

Delmulle, L., Bellahcène, A., Dhooge, W., Comhaire, F., Roelens, F., Huvaere, K., Heyerick, A., Castronovo, V., De Keukeleire, D., 2006. Anti-proliferative properties of prenylated flavonoids from hops (Humulus lupulus L.) in human prostate cancer cell lines. Phytomedicine 13, 732-734.

Fayeulle, N., Vallverdu-Queralt, A., Meudec, E., Hue, C., Boulanger, R., Cheynier, V., Sommerer, N., 2018. Characterization of new flavan-3-ol derivatives in fermented cocoa beans. Food Chem. 259, 207-212.

Frankel, E.N., 2005. Lipid Oxidation, 2nd ed. Oily Press.

Gadkari, P.V., Balaraman, M., 2015. Catechins: sources, extraction and encapsulation: a review. Food Bioprod. Process. 93, 122-138.

Gomes, F.M.S., da Cunha Xavier, J., dos Santos, J.F.S., de Matos, Y.M.L.S., Tintino, S.R. de Freitas, T.S., Coutinho, H.D.M., 2018. Evaluation of antibacterial and modifying action of catechin antibiotics in resistant strains. Microb. Pathog. 115, 175-178.

Grzesik, M., Naparło, K., Bartosz, G., Sadowska-Bartosz, I., 2018. Antioxidant properties of catechins: comparison with other antioxidants. Food Chem. 241, 480-492.

Inui, T., Okumura, K., Matsui, H., Hosoya, T., Kumazawa, S., 2017. Effect of harvest time on some in vitro functional properties of hop polyphenols. Food Chem. 225, 69-76.

Kampa, M., Hatzoglou, A., Notas, G., Damianaki, A., Bakogeorgou, E., Gemetzi, C., Kouroumalis, E., Martin, P.-M., Castanas, E., 2000. Wine antioxidant polyphenols inhibit the proliferation of human prostate cancer cell lines. Nutr. Cancer 37, 223-233.

Karabin, M., Hudcova, T., Jelinek, L., Dostalek, P., 2015. Biotransformations and biological activities of hop flavonoids. Biotechnol. Adv. 33, 1063-1090.

Keskin, S., Sirin, Y., Cakir, H.E., Keskin, M., 2018. An investigation of Humulus lupulus L. phenolic composition, antioxidant capacity and inhibition properties of clinically important enzymes. S. Afr. J. Bot. 120, 170-174.

Ma, W., Waffo-Téguo, P., Jourdes, M., Li, H., Teissedre, P.-L., 2018. First evidence of epicatechin vanillate in grape seed and red wine. Food Chem. 259, 304-310.

Machado, J.C., Faria, M.A., Melo, A., Ferreira, Isabel M.P.L.V.O., 2017. Antiproliferative effect of beer and hop compounds against human colorectal adenocarcinome Caco-2 cells. J. Funct. Foods 36, 255-261.

Miranda, C.L., Stevens, J.F., Helmrich, A., Henderson, M.C., Rodriguez, R.J., Yang, Y.H., Deinzer, M.L., Barnes, D.W., Buhler, D.R., 1999. Antiproliferative and cytotoxic effects of prenylated flavonoids from hops (Humulus lupulus) in human cancer cell lines. Food Chem. Toxicol. 37, 271-285.

Monteiro, R., Faria, A., Azevedo, I., Calhau, C., 2007. Modulation of breast cancer cell survival by aromatase inhibiting hop (Humulus lupulus L.) flavonoids. J. Steroid Biochem. Mol. Biol. 105, 124-130.

Morales, P., Carvalho, A.M., Sánchez-Mata, M.C., Cámara, M., Molina, M., Ferreira, I.C.F.R., 2012. Tocopherol composition and antioxidant activity of Spanish wild vegetables. Genet. Resour. Crop Evol. 59, 851-863.

Multari, S., Neacsu, M., Scobbie, L., Cantlay, L., Duncan, G., Vaughan, N., Stewart, D., Russell, W.R., 2016. Nutritional and phytochemical content of high-protein crops. J. Agric. Food Chem. 64, 7800-7811.

Natarajan, P., Katta, S., Andrei, I., Babu Rao Ambati, V., Leonida, M., Haas, G.J., 2008. Positive antibacterial co-action between hop (Humulus lupulus) constituents and selected antibiotics. Phytomedicine 15, 194-201.

Nionelli, L., Pontonio, E., Gobbetti, M., Rizzello, C.G., 2018. Use of hop extract as antifungal ingredient for bread making and selection of autochthonous resistant starters for sourdough fermentation. Int. J. Food Microbiol. 266, 173-182.

Panat, N.A., Maurya, D.K., Ghaskadbi, S.S., Sandur, S.K., 2016. Troxerutin, a plant flavonoid, protects cells against oxidative stress-induced cell death through radical scavenging mechanism. Food Chem. 194, 32-45.

Pereira, C., Calhelha, R.C., Barros, L., Ferreira, I.C.F.R., 2013. Antioxidant properties, anti-hepatocellular carcinoma activity and hepatotoxicity of artichoke, milk thistle and borututu. Ind. Crops Prod. 49, 61-65.

Pinela, J., Barros, L., Dueñas, M., Carvalho, A.M., Santos-Buelga, C., Ferreira, I.C.F.R., 2012. Antioxidant activity, ascorbic acid, phenolic compounds and sugars of wild and commercial Tuberaria lignosa samples: effects of drying and oral preparation methods. 
Food Chem. 135, 1028-1035.

Sławińska-Brych, A., Król, S.K., Dmoszyńska-Graniczka, M., Zdzisińska, B., Stepulak, A., Gagoś, M., 2015. Xanthohumol inhibits cell cycle progression and proliferation of larynx cancer cells in vitro. Chem. Biol. Interact. 240, 110-118.

Sławińska-Brych, A., Zdzisińska, B., Dmoszyńska-Graniczka, M., Jeleniewicz, W., Kurzepa, J., Gagoś, M., Stepulak, A., 2016. Xanthohumol inhibits the extracellular signal regulated kinase (ERK) signalling pathway and suppresses cell growth of lung adenocarcinoma cells. Toxicology 357-358, 65-73.

Small, E., 1978. A numerical and nomenclatural analysis of morpho-geographic taxa of Humulus. Syst. Bot. 3, 37.

Small, E., 1980. The relationships of hop cultivars and wild variants of Humulus lupulus. Can. J. Bot. 58, 676-686.

Smeriglio, A., Galati, E.M., Monforte, M.T., Lanuzza, F., D’Angelo, V., Circosta, C., 2016. Polyphenolic compounds and antioxidant activity of cold-pressed seed oil from finola cultivar of Cannabis sativa L. Phyther. Res. 30, 1298-1307.

Soković, M., van Griensven, L.J.L.D., 2006. Antimicrobial activity of essential oils and their components against the three major pathogens of the cultivated button mushroom, Agaricus bisporus. Eur. J. Plant Pathol. 116, 211-224.

Soković, M., Glamočlija, J., Marin, P.D., Brkić, D., Griensven, L.J.L.Dvan, Soković, M., Glamočlija, J., Marin, P.D., Brkić, D., Griensven, L.J.L.Dvan, 2010. Antibacterial effects of the essential oils of commonly consumed medicinal herbs using an in vitro model. Molecules 15, 7532-7546.
Sowndhararajan, K., Kang, S.C., 2013. Free radical scavenging activity from different extracts of leaves of Bauhinia vahlii Wight \& Arn. Saudi J. Biol. Sci. 20, 319-325.

Stevens, J.F., Page, J.E., 2004. Xanthohumol and related prenylflavonoids from hops and beer: to your good health!. Phytochemistry 65, 1317-1330.

Takwa, S., Caleja, C., Barreira, J.C.M., Soković, M., Achour, L., Barros, L., Ferreira, I.C.F.R., 2018. Arbutus unedo L. And Ocimum basilicum L. As sources of natural preservatives for food industry: a case study using loaf bread. LWT - Food Sci. Technol. $88,47-55$.

Tardío, J., Sánchez-Mata, M., de, C., Morales, R., Molina, M., García-Herrera, P., Morales, P., Díez-Marqués, C., Fernández-Ruiz, V., Cámara, M., Pardo-de-Santayana, M., Matallana-González, M.C., Ruiz-Rodríguez, B.M., Sánchez-Mata, D., Torija-Isasa, M.E., Guil-Guerrero, J.L., Boussalah, N., 2016. Ethnobotanical and food composition monographs of selected mediterranean wild edible plants. Mediterranean Wild Edible Plants: Enthnobotany and Food Composition Tables. Springer, New York, NY, pp. $273-470$.

Vaz, J.A., Heleno, S.A., Martins, A., Almeida, G.M., Vasconcelos, M.H., Ferreira, I.C.F.R., 2010. Wild mushrooms Clitocybe alexandri and Lepista inversa: In vitro antioxidant activity and growth inhibition of human tumour cell lines. Food Chem. Toxicol. 48, 2881-2884.

Yilmaz, Y., 2006. Novel uses of catechins in foods. Trends Food Sci. Technol. 17, 64-71. Zanoli, P., Zavatti, M., 2008. Pharmacognostic and pharmacological profile of Humulus lupulus L. J. Ethnopharmacol. 116, 383-396. 